\title{
The Civil and CRIMinal APPlications of THE IDENTIFICATION DOCTRINE: ARGUMENTS FOR HARMONIZATION
}

\author{
DARCY L. MACPHERSON
}

The identification doctrine refers to the attribution of mental states to a corporation. This article analyzes the no types of simations in which this doctrine is used. The first is where the Crown wishes to hold a corporation liable for crimes requiring proof of mental fault. Canadian Dredge \& Dock Co. Lid. v. R. serves as the cornerstone case in which the doctrine is firmly' established as a "sword" against corporations in the criminal lan. The second situation in which the doctrine has been used is where the corporation sues in tort, and the defendant wishes to say that the mental stale of the plaintiff corporation disentiles recovery: In other words, the doctrine can be used us a "shicld" for individnals against claims in tort by corporations.

Legislarive amendments wo the Criminal Code have alsered criteria for the doctrine in the criminal law: These changes do not affect the "shield" use of the doctrine, which is still governed by the common law: The author argues for the harmonization of the common law doctrine with its criminal legislavive counterpart.
La doctrine d'identification fait rejérence an fait d'attribuer des citats mentanex à une corporation. Cot arficle analyse dewa types de situations où cerfe doctrine est utiliscic. La premicre itom lorsque la Couronne desire tenir une corporation responsable pour des crimes exigeant une preuve de mens rea. Canadian Dredge \& Dock Co. Lid. c. R. constilue la cause fondamentale où la doctrine a été fermemem etablic en tant qu' a épe * contre les corporations dans le droit penal. La deuxieme situation oi la doctrine a éte utilisé est lorsqu'une corporation intente une action en responsabilifi délictuelle et que le defendeur veut dire que l'état mental de la corporation demanderesse prive le droil de recouver. En dautres mots, la doctrine peitl senir de " bouclier " $"$ proveger des personmes contre des poursuites en responsubilité delictuelle de corporations.

Les amendements législatifs au Code criminel ont modifie les crisères de la docirine dans le droir pénal. Ces changements ne changen pas I'urilisation " bouclier " de la dactrine. qui est toujours régie par la common law: I. auteur milite pour I harmonisation de la doctrine de la common law avec sa contrepartice legislative pénale.

\section{TABLE OF CONTENTS}

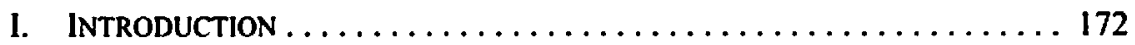

II. INTEREST IN THE HART DECISION $\ldots \ldots \ldots \ldots \ldots \ldots \ldots \ldots \ldots \ldots \ldots$

III. THE IDENTIFICATION DOCTRINE $\ldots \ldots \ldots \ldots \ldots \ldots \ldots \ldots \ldots \ldots \ldots \ldots \ldots$

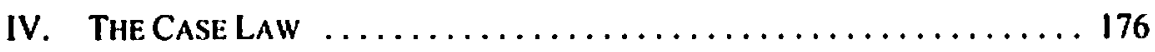

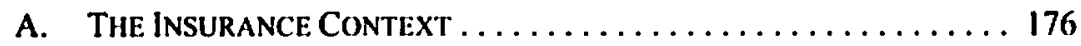

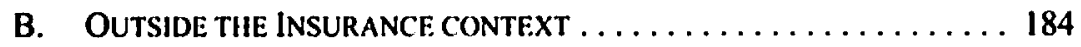

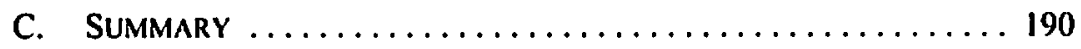

V. THE IMPORTANCE OF THE HART DECSION $\ldots \ldots \ldots \ldots \ldots \ldots \ldots \ldots 191$

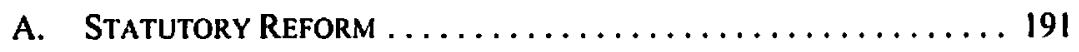

B. THREE RATIONALES IN FavOUR OF

HARMONIZATION .......................... 193

Assistant Prolessor, liaculty of L.aw, University of Manitoba; Associate, Marcel A. Desautels Centre for Private Enterprise and the Law, University of Manitoba. Generous linancial support for this project was received from the Legal Researeh Institute and the University Research Grants Program, University of Manitoba. Thanks are also owed to Professor John Irvine, whose tireless work to refine both my thoughts and the clarity with which those thoughts are expressed improved the final product immeasurably. The research assistance of Ryan Brolund, Doug Schweitzer, and Daniel Watts is also gratefully acknowledged. 
C. Common LaW vs. Statute - Which Should Prevall? . . . . 196

D. WHAT IF THE CRIMINAL ATtRIBUTION RULE IS

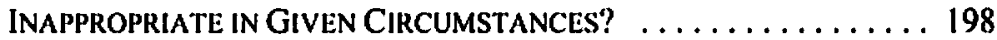

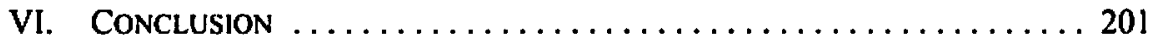

\section{INTRODUCTION}

Canadian Dredge \& Dock Co. v. R.' is one of the most important cases in criminal law. As most practitioners are already aware, this case serves as the definitive statement by the Supreme Court of Canada as to the manner in which a corporation can be held liable for crimes requiring proof of an element of mental fault, ${ }^{2}$ using the idea commonly referred to as either the "identification" or "attribution" doctrine. ${ }^{3}$ In other words, the doctrine is a "sword" of the Crown to be used against a corporation in the course of whose business criminal wrongdoing occurs. However, as can be seen in Hart Building Supplies Ltd. v. Deloitte \& Touche, ${ }^{4}$ the authority of Canadian Dredge (and the identification doctrine on which its conclusions are based) can also be used as a "shield" by a defendant sued by a corporation in tort.

This article begins first with an explanation of what piqued my interest in this area. Second, the article briefly reviews the elements of the identification doctrine. The third section discusses the relevant cases that consider the identification doctrine as a shield in the civil context. Subsequently, recent legislative changes to the identification doctrine in the criminal context are reviewed. After explaining the substance of these changes, this article concludes that the identification doctrine in the civil law context - notably in the areas of both torts and insurance — should be harmonized with the criminal law context, for reasons that will become apparent.

[1985] I S.C.R. 662 [Camadian Dredge].

An "element of mental fault" is a phrase that is meant to encompass both subjective mens rea (intention. recklessness, etc.) as well as objective tests for liability (c.g. gross or criminal negligence).

3 While one could argue that the choice between "identification" and "attribution" might suggest sublle variations in the meaning to be ascribed to the doctrine, the cases seem to use the two terms relatively interchangeably. For example, in Canadian Dredge, supra note I at 691. Fstey J. writes:

Criminal responsibility in our courts thus far has been achieved in the mens rea offences by the attribution to the corporation of the acts of its employees and agents on the more limited basis of the doctrine of the directing mind or identification.... By what appears to be the same purely pragmatic reasoning, the courts of the United Kingdom find criminal liability in a corporation only by the attribution to it of the conduct of its employees and agents whene those natural persons represent the core, mind and spirit of the corporation.

As such, attribution is a necessary pant of the identification doctrine. Since the two terms refer to the same concept, they will be used interchangeably in this article. However, both terms are to be distinguished from vicarious criminal liability of corporations. Immedialely following the above excerpt from Canadian Dredge, Estey J. writes: "The United States federal courts are inclined, as we have sten, to find criminal liability in the corporation by vicarious liubility where any employec-agent commits. in the course of his employment, the criminal act" (at 691). Thus, Estey J. draws a clear distinction between identification or attribution, used by the Canadian and U.K. courts on the one hand, and vicarious criminal liability, the approach of the U.S. courts on the other. 


\section{INTEREST IN THE HART DECISION}

In the summer of 2004, a colleague found a recent case by the name of Hart Building Supplies Ltd. v. Deloitte \& Touche, and placed it on my desk. The facts of Hart can be stated rather briefly:

[I]t was found, on a summary trial, that Larson, the president of Hart, Larson, had fraudulently misrepresented the value of Hart's inventory over a number of years in an effort to benefit Hart. The defendant served as Hart's auditor during pan of the relevant period. The audits done by the defendant were based on representations that Larson gave on behalf of Hart. Larson knew these representations not to be true at the time he gave them. These representations included acknowledgements of the responsibility of Hart for the fair presentation of its financial statements, representations that the statements were free of material errors and omissions, assurances of no irregularities on the part of relevant managers or employees, and representations as to the accuracy of stated inventory values.

The defendant's annual audits never discovered the mistepresentations until Larson confessed to his misdeeds in September 2000. Approximately one month later, the plaintifl's bank placed Hart in receivership. In 2001, Hart sued its auditor for negligence.

The Court found that (1) Larson was a directing mind of Hart; (2) the actions of Larson were the actions of the corporation; and therefore, (3) the corporation could not sue its auditors for what were the corporation's own misdeeds. ${ }^{6}$

As a professor of corporate law, I have always focused on the identification doctrine in discussing the criminal liability of corporations, as was discussed in Canadian Dredge and its progeny. Consequently, the Hart decision was intriguing in the sense that the identification doctrine was being used against a corporate plaintiff to defend a civil suit. It was therefore the potential similarities and differences between the civil context and its criminal counterpart that served as the underlying motivation for the development of this article. ${ }^{7}$

5 Darcy L. MacPherson, "Emaciating the Stalutory Audit - A Comment on Hart Building Supplies I.td. v. Delointe \& Touche" (2005) 41 Can. Bus. L.J. 471 at $471-72$ |MacPherson, "Emaciating the Statutory Audit"]. Ste also ibid. at paras. 1-25.

- See Harl, ibidl. at paras. 51.63.

2. As it turns out, the one case to consider Hart since its release shows the potentially broad impact of the decision. In /lickman Equipment (1985) Lud. (Receivership), Re, 2005 NL.TD 146, 251 NId. \& P.E.I.R. 185 (S.C. (T.D.)) [Hickman], a receiver was seeking court approval for the reimbursement of the costs of the receivership. Part of the costs were associated with an investigation into a possible claim in negligence with respect to the auditing services provided by (ironically enough) Deloitte \& Touche L.LP. the same firm involved in the Hart case. Three secured creditors of the now bankrupl company opposed the approval of costs. The Court put the case for the creditors very succinctly when Hall J. wrote: "[T]he preliminary investigation conducled by [the Receiver] at a cost to the receivership of $\$ 175,000$ had not. in the minds of these secured creditors, produced sufficient results to justify lurther expenditures being incurred in further investigation" (at para. 6). Some creditors who had advanced money on the strength of the audits felt that they had an independent claim against Deloitte \& Touche L.L.P. The allegation of the secured creditors was that the decision in /Jurt should have caused the Receiver to stop its work in pursuing recovery against Deloitte \& Touche LLP (at para. 17). The Coun disagreed because the investigation had not established that a "directing mind" of the corporation was involved in the wrongdoing (at para. 17). Note that although Hickman was decided in 2005, after the Act 10 Amend the Criminal Code came into force on 31 March 2004 (see infra notes 107, 108 and accompanying text), 
However, before turning to the substance of this article, a few words are necessary to explain what the article is not about. It is not suggested that the application of the identification doctrine in any form is appropriate in the circumstances presented in Hart; in fact, quite the contrary is true: the identification doctrine has no application whatsoever on the facts of $\mathrm{Harr}^{8}$

This article focuses on the fact that, owing to certain statutory changes, the Canadian courts now have two different versions of the identification doctrine from which to choose when applying the doctrine in a civil context. Assuming that the identification doctrine does apply in a given set of circumstances, which of the two versions should apply?

\section{ThE IDENTIFICATION DOCTRINE}

The identification doctrine was first introduced at common law in a case where a civil plaintiff had to prove "actual fault or privity" of a corporate defendant." Even though a corporation is a separate legal "person" from those who hold its shares or control its operations, ${ }^{10}$ the fact remains that it has no "brain" of its own. Therefore, the court must decide whether there is an individual who committed the actus reus with the requisite element of mental fault. Having thus attributed the tort or crime in issue to the individual, the court then has to determine whether the individual is sufficiently high up in the corporate hierarchy for the court to hold that the individual's mental state should be attributed to the corporation." The same doctrine was later applied in order to determine the criminal liability

the events at issue in the case had oecurred up to and including 200I (at para. 4). Therefore, cven if the civil and criminal applications of the identification doetrine were to be harmonized (as suggested below). as of the time of the events in Hickman, they would not be harmonized with the statule because the statule was not yet in force (which occurred in March 2004) or passed (which occurred in November 2003).

8 This argument has already been made previously and it is unnecessary to repeat it herc. Sec supra note 5.

- See Lennard's Carrying Co.. Lid. v. Asiatic Petroleum Co., Lid., [1915] A.C. 705 at 713 (H.L..) [Lennard's Carrying]. For a similar case in the Canadian context, see Rhöne v. Peter A.B. Widener, [1993] I S.C.R. 497 at 507 [Rhöne].

10 See Salomon v. Salomon \& Co., [1897] A.C. 22 (H.L.) [Salomem] and the Canuda Business Corporations ACt, R.S.C. 1985, c. C-44, s. I5(I) [CBCA].

1" For those people who have a more prolound understanding of substantive criminal law than me, the term "attribution" can be seen to be problematic. For them, in criminal law, the state cannot convict one person of a mens rea crime by attributing the mental state of a second person to the first. For such criminal law experts, the identification doctrine is seen as determining the quality of certain types of evidence, with respect to the relationship between individuals and the corporation. For an example of the connection of the identification to evidentiary concerns, see Director of Public Prosecutions v. Kent and Sussex Contractors. Lid., [1944] K.B. 146 (Div. Ct.) at 155-56. The Supreme Court begins its decision in Canadian Dredge, supra note I, by detailing that, historically, corporations were generally immune from criminal prosecution and that this was gradually relaxed over time (at 674-79). The reasoning in Canadian Dredge is designed to make corporations liable for all mens rea offences. While evidentiary coneerns may be a small part of the raison d'être of the identification doctrine, the Supreme Court of Canada has made it quite elear that the identification doctrine is a mechanism to change the suhstunce of criminal law, and is not merely evidentiary in nature. To these criminal law experts, the term "identification," as opposed to "attribution." is better suited to the task at hand. While this may or may not be true (and, to be fair, there are legitimate arguments on both sides of this issue), the fact remains that. at least in the criminal sphere, the term attribution is still currenlly acceptable. See Canadian Dredge, supra note 1 at 678-79, 683-84, 687, 689, 691, 693-94. In the civil context, sce c.g. Rhone, supra note 9 at 520 . Regardless of the potential validity of these linguistic differences, for the 
of corporations. ${ }^{12}$ Therefore, this doctrine had its genesis as a sword for those alleging wrongdoing, be it civil plaintiffs or criminal prosecutors, to prove the actual fault, as opposed to the vicarious responsibility, of the corporation both in tort and in criminal law.

Historically, in order to show corporate liability in such a case, the plaintiff had to prove that the person committing the tort or the crime was a "directing mind" of the corporation in the area where the misdeed occurred. This meant that the person had to have the power to design and implement corporate policy, as opposed to simply being able to carry out policy designed by others. ${ }^{13}$ If the person was a directing mind in the area of corporate activity where the misdeed occurred, and was acting within his or her authority, then the corporation and the directing mind become one and the same for these purposes. ${ }^{14}$

At common law, ${ }^{15}$ there are three defences available in this situation. ${ }^{16}$ First, if the actions of the individual are outside the scope of the individual's authority, regardless of the individual's seniority, he will not be considered to be acting as a directing mind. Second, if there was neither an intention to benefit, nor the conferral of an actual benefit on the corporation, the employee is not acting as a directing mind of the corporation. Third, if the employee is attempting to defraud the corporation, the identification doctrine does not apply."

purposes of the points made herein, little, if anything, turms on the language used. Therefore, the terms attribution and identification (and their derivatives) will be used interchangeably throughout. On this point, see also supra note 3.

Canadian Dredge, supra note 1; R. v. St. Lawrence Corp. L.d. (1969), 2 O.R. 305 (C.A.) [Si. Lawrence].

1 Rhone, supra note 9 at 521 . The common law in this area for the purposes of the criminal law has been the subject of significant statutory reform. For a discussion of this reform, see infra note 106 and accompanying text.

14 Canadian Dredge, supra note 1 at 699.

is As a matter of language, some might suggest that the term "common law" is inappropriate. In one sense, corporate law is by definition statutory in nature; therefore, if the law deals with corporations, it must have a statutory basis. Furthermorc, the use of the identification doctrine originally arose out of the English case Lennard's Carrying, supra note 9, under the United Kingdom's Merchant Shipping Act, 1894 (U.K.), 57 \& 58 Vict., c. 60, s. 502. The House of Lords, in developing the identification doctrine, was trying to give effect to the statutory language with which it was confronted. Thus, for those who subseribe to this line of reasoning, the common law label does not, strictly speaking, apply. However. prior to the passage of the Act to Amend the Criminal Code, infra note 107. Uhere was no mention of how mental states were to be attributed or ascribed to a corporation in any statute. The statute demanded that mental states be so ascribed. How this was accomplished, however, was purely a matter of the judicial imagination. Thus, the doctrine of attribution (or identification) cannot be said to be a matter of statutory interpretation. However, the identification doctrine is due at least in part to the fact that a corporation is a juristic person. This is a statutory concept outlined in the $C B C A$, supra note $10, \mathrm{~s} .15$. In the final analysis, the language of "common law" draws a useful distinction for our purposes. When I refer to the "common law," I mean the period of time where there was no specific statutory provisions dealing with the attribution of mental states to corporations, that is, any casts that arose prior to the passage of the Act to Amend the Criminal Code. Where I refer to the "statute" on the other hand. I am focused on Parliament's statutory reform attempt in the aforementioned statule.

These are referred to as "defences" in several places in Camadian Dredge, supra note I. including. among others, at 698, 705-706. Therefore, this article adopts the terminology used by Estey J. However, it is equally clear that lechnically, these are not defences at all. Rather, the Crown must prove that these defences do not apply. See Canadian Dredge, supra note I at 713-14. 
In both Canadian Dredge and Rhone, the defendant corporation was brought to court to answer allegations of wrongdoing. In both cases, the doctrine was utilized as a sword against the corporation. But in the last 30 years or so, the identification doctrine has also been used by defendants who are sued by corporate plaintiffs. In other words, the identification doctrine has served as a shield against civil actions by corporations.

\section{THE CASE Law}

The cases arising in this area of the law have largely been dominated by concerns related to the law of insurance; thus, it is necessary to first review the relevant case law and then consider other areas of law where the identification doctrine is used as a defence.

\section{A. The Insurance CONTEXT}

Insurance companies have been particularly prone to trying to use the identification doctrine as a shield. Their argument typically runs as follows: an employee of the corporation does something that causes a loss to the corporation. The corporation has an insurance policy to protect against loss due to employee misconduct. A claim is then made by the corporation against that insurance policy. The policy contains an exclusionary clause, indicating that the insurer is not liable for fraudulent actions of the insured itself. The insurer then claims that the fraudulent employee is the directing mind of the corporation. If this is so, the insurer says, the fraud is that of the corporation, because the mens rea of the individual employee is also that of the corporation. Thus, according to the insurer, recovery under the policy is barred by this exclusion.

The decisions in this area have been somewhat inconsistent in their application of the identification doctrine. Some of the more important cases will now be considered in chronological order, and then conclusions will be drawn from this review.

In Sigurdson v. Fidelity Insur. Co. of Can., ${ }^{18}$ a corporation called Surety Investments Ltd. (Surety), which had been licensed as a broker-dealer in British Columbia, was involved in bankruptcy proceedings. Surety was run at the relevant time by two men, Luttin and Eccles. ${ }^{19}$ Surety had an insurance policy to protect against "any loss through any dishonest, fraudulent or criminal act of any of the employees."20 The trial judge accepted that the two men had treated Surety's money as their own. ${ }^{21}$ Through a variety of procedures, Luttin and Eccles

[1977] 4 W.W.R. 231 (B.C.S.C.), rev'd on other grounds (1980), 110 D.L.R. (3d) 491 (B.C.C.A.) [Sigurdson]. This case significanlly predates the decision of the Supreme Court of Canada in Canadion Dredge, supra note 1. Nonetheless, since the case deals with the attribution of a mental state of an officer to the corporation which the oflieer serves, in the conlext of a defence by an insurer, the case is relevant to our discussion herc. This is so even though the case does not use the terminology later adopted in Canadian Dredge. The variation by the British Columbia Court of Appeal involved legal issues of whether the actions of the individuals at issue in that case were in fact "fraudulent" us required by the insurance policy. However, the Court did not consider whether the fraud of the individuals could be attributed to the corporation, thereby disentitling the insured corporation from recovery. The Court of Appeal's judgment is therefore len aside entirely from the discussion.

lbid. at 256. 
removed money from Surety. Once in bankruptcy proceedings, the trustee in bankruptcy sought to recover from the insurer for the losses to Surety by the acts of Luttin and Eccles, acts alleged to be dishonest and fraudulent. The insurer opposed the claim on two grounds: first, it argued that the knowledge of Luttin and Eccles was the knowledge of Surety, and therefore, the actions of Luttin and Eccles were neither fraudulent nor dishonest vis-à-vis that company. Second, the insurer claimed its policy required that (a) all losses be reported within 90 days of discovery, ${ }^{22}$ and (b) the coverage in respect of an employee under the policy was immediately terminated upon the discovery of any dishonest or fraudulent act on the part of such employee. ${ }^{23}$ Therefore, the insurer claimed that Suraty "discovered" the acts of Luttin and Eccles as soon as they performed acts, and therefore, immediately after the first act of fraud or dishonesty, the acts of Luttin and Eccles were no longer covered under the policy. ${ }^{24}$ Moreover, more than $\mathbf{9 0}$ days had passed since the first act was committed. Consequently, the insurer argued that Surety was not entitled to claim under the policy in respect of the acts of Luttin and Eccles.

The British Columbia Supreme Court disagreed. Justice McKenzie held that in the circumstances, it would be unfair to disentitle the company since the people charged with discovering the wrongdoing were in fact committing it. He wrote:

Gluckstein v. Barnes, [1900] A.C. 240 , has some borrowable words which fit the present situation ...:

“...the company was paralyzed so far as vigilance and criticism were concemed; for the board-room was occupied by the enemy."

In the present case the enemy seldom occupied the boardrom but he was always present inside the very skin of the company's sole officers and top employees, luttin and Eceles. It runs contrary to common sense to suggest that Luttin or Eceles would initiate proceedings on behall of Surcty to recover for it from lFidelity losses to Surety which were Luttin's and Eccles' gains.

There is another tantalizing aspect of this in that Luttin stoutly maintained through the trial that he and Eccles did no wrong. Luttin has not yet "discovered" any wrongdoing so in his mind there never has been any reportable wrongdoing. Presumably Luttin will only discover lis wrongdoing upon reading these reasons for judgment. The discovery of the losses to Surely was made by others after luttin's depanture and even then the losses could only be matters of opinion as indeed the question of fraud and dishonesty also had to be. It was only when a body of fact had been found by the investigaters which would justify a careful and prident man in forming the opinion that losses had been sustained by fraud and dishonesly that the initial step toward recovery under the bond could be taken. ${ }^{25}$

What is intriguing about this quote is that it manages to bring together three relatively disparate elements to justify its conclusion in favour of the insured corporation. The first, element taken from the earlier part of the quote, is in essence suggesting that it is unreasonable to expect the separate legal person, the corporation, to exercise supervision 
over the wrongdoing of its officers when those officers were in constant and effectual control of the corporation. The law generally does not expect the impossible. Therefore, if it would be demanding the impossible from the corporation to apply the identification doctrine in the circumstances of this case (that is, to require reporting from Luttin or Eccles), then the clear implication is that McKenzie J. would not do so.

The second element finds expression in the following sentence: "It runs contrary to common sense to suggest that Luttin or Eccles would initiate proceedings on behalf of Surety to recover for it from Fidelity losses to Surety which were Luttin's and Eccles' gains." ${ }^{.26}$ This is essentially the same concern that Estey J. would refer to in Canadian Dredge as the "fraud on the corporation" defence to the identification doctrine. ${ }^{27}$ Therefore, approximately eight years prior to the Supreme Court of Canada decision in Canadian Dredge, without using the language of the identification doctrine, McKenzie J. essentially anticipated one of its tenets in the Sigurdson decision.

The third element is found in the final paragraph of the longer quotation above. In order to buttress the conclusion in favour of the insured, the British Columbia Supreme Court relies on the fact that the words of the exclusionary clause did not apply. Issues of contractual interpretation will be dealt with below, during the discussion of International Nesmont Industrial Corp. v. Continental Insurance Co. of Canada ${ }^{28}$ In an effort to avoid unnecessary repetition, and given that the issues of contractual interpretation are concerns which are conceptually independent of the identification doctrine, it is unnecessary to address them in detail here. It is sufficient to say that McKenzie J. is, with respect, quite correct to determine the scope of the exclusion, whether or not the identification doctrine applies to the circumstances at hand..$^{29}$

Ibid.

Supra note 1 at 701 .

2002 BCCA 136, 99 B.C.L.R. (3d) 306 (C.A.) [Nesmont Industrial (C.A.)].

This is different from the argument accepted by the British Columbia Courn of Appeal in Nesmont Industrial, ibid. As will be discussed below, the Court in Nesmont Industrial held that the wording of the contract was sufficient by itself to oust the application of the identification doctrine. On the other hand, the British Columbia Supreme Court in Sigurdson, supra note 18 at 264, held (if it were to use modern language) that even if the identification doctrine were to apply. the wording of the exclusion was not sufficient to cover what had happened here. In other words, the application of the identification doctrine is determined independently of the wording of the particular insurance policy at issue. After the issue of the application of the identification doctrine is resolved, then the canons of contractual interpretation must be used to judge the scope of the exclusion. It just so happens that, in Sigurdson, the answer to cach of these questions independently points in favour of the insured. However, the Court of Appeal in Nesmom industrial conflates these two questions, using the words of the contract of insurance to justify the non-application of the identilication doctrine. This leads to a number of conceptual problems, which will be discussed below. 
The next case of interest is found in Clarkson Co. Lid. v. Canadian Indemnity Co. ${ }^{30}$ In this case, three directors and a salesman of a brokerage firm perpetrated a fraud through the unauthorized use of client accounts. The fraud was perpetrated in an effort, among other things, to avoid running a foul of capital-maintenance requirements prescribed by the Toronto Stock Exchange. The corporation at issue later went bankrupt. Its trustee in bankruptcy then sued under a fidelity bond issued by the defendant insurer, which was to protect the plaintiff company against losses resulting from "any dishonest, fraudulent or criminal act"31 committed by employees of the company. The trial judge determined that the three directors, two of whom were also officers, were also directing minds of the company. ${ }^{32}$ The Court held that, as a result, the actions of these employees were in fact the actions of the corporation. It followed from this conclusion that the corporation could not recover under the fidelity bond issued to it by the defendant because an insured cannot profit from its own bad acts. ${ }^{33}$

In Oger v. Chiefscope Inc., ${ }^{34}$ the plaintiff had consigned his car to the corporate defendant for the purposes of sale. ${ }^{35}$ The vehicle was fraudulently taken by two employees of the corporate defendant. ${ }^{36}$ The employees, who were also the principals of the corporate defendant, ${ }^{37}$ took the car for their own purposes, rather than the purposes of the corporate defendant. ${ }^{38}$ The plaintiff claimed against an insurance policy issued in favour of the defendant. The policy provided for coverage in the event of employee fraud, ${ }^{39}$ with a specific exception for fraud or dishonest acts of the insured - in this case, the defendant corporation. ${ }^{40}$ The plaintiff stepped into the shoes of the defendant and claimed against the policy. The insurance company claimed that, since fraudulent employees were in effective control of the corporation, they were the directing minds of the corporation and thus, the corporation itself was fraudulent. ${ }^{41}$ Therefore, the insurance company claimed that it was not liable. The trial judge agreed that the fraudulent employees were directing minds of the corporation. ${ }^{42}$

(1979), 25 O.R. (2d) 281 (H.C.J.) [Clarkson (H.C.J.)], affd (1981), 129 D.L.R. (3d) 511 (C.A.) [Clarkson (C.A.)]. Leave to appeal to the Supreme Court of Canada dismissed 8 December 1981, per Laskin C.J.C., Estey and McIntyre JJ. Interestingly, the decisions of both the High Court of Justice and the Court of Appeal signilicantly predate the decision of the Supreme Court of Canada in Canadian Dredge, supra nole 1 . Nonetheless, it is quite clear that the resolutions ol the two disputes share themes in common and are largely based on the same principles. Therefore. Clarkson is included in the discussion here.

Clarkson (H.C.J.), ibid. at 282.

lbid. at 283.

Ibid. at 301. These reasons of Keith J. were expressly adopted by the Court of Appeal (Clarkson (C.A.) at 511).

(1996), 29 O.R. (3d) 215 (Gen. Div.) [Oger (Gen. Div.)], aff d (1998), 113 O.A.C. 373 [Oger (C.A.)]. Oger (Gen. Div.), ibid. at 216.

lbid.

Oger (Gen. Div.), ibid. at 216-17; Oger (C.A.), supra note 34 at 374. For the sake of clarity, I do not believe that the use of the term "principals" is a reference to agency law. Ruther. from the circumstances of the case, it is reasonably elear that principals refers to the individuals who have control over the operations of the comoration at issuc.

Oger (C.A.), ibid. at 374.

Oger (Gen. Div.), supra note 34 at 217; Oger (C.A.), ibid. at 374.

Oger (C.A.), ibid.

Oger (C.A.), ibid. at 374.

Oger (Gen. Div.), supra note 34 at 221; Oger (C.A.) ibid. at 374. 
However, the inquiry did not end there. The Court continued its analysis and held that the employees were acting in fraud of the corporation and therefore, the third defence to the identification doctrine (referred to carlier) applied, and the acts of the fraudulent employees were not attributable to the corporation. The corporation was not fraudulent, and could therefore recover under the policy. Therefore, while the identification doctrine might otherwise have been in issuc, the Court held that its limits had been exceeded. ${ }^{43}$

A similar result was reached in Eastern Chrysler Plymouth Inc. v. Manisoba Public Instrance Corp. ${ }^{\text {th }}$ In this case, the president of the plaintiff corporation (who was also its general manager and a director) drove a vehicle belonging to his employer while extremely intoxicated. An accident resulted and the vehicle had to be written off. The defendant insurer opposed a motion for summary judgment based in part on the fact that the driver was a directing mind of the corporation and it was therefore argued that his actions and mental state were to be attributed to the corporation. If so, then the corporation then should not be able to recover. ${ }^{45}$ The Manitoba Court of Queen's Bench held that the first defence referred to earlier - acting outside the scope of authority - applied on these facts. ${ }^{46}$ In other words, even though the individual was a senior corporate official and thus a directing mind, his mental state should not be attributed to the corporation because drinking and driving was not done in that capacity. Therefore, even though the identification doctrine was acknowledged, its limits had once again been exceeded.

In Nesmont Industrial, ${ }^{\text {s7 }}$ there was a fidelity insurance policy issued by the defendant to cover fraudulent acts of employees. Two senior employees of the plaintiff, through a complicated series of transactions involving both the issuance of false invoices ${ }^{48}$ and a process called "salting," caused the corporation to lose millions of dollars. Although the main claim was dismissed for reasons not relevant to the identification doctrine, ${ }^{50}$ a prima facie claim for a smaller amount was made out. At the trial level, the British Columbia

Oger (Gen. Div.), ihid:; Oger (C.A.), ibid. at 374-75. Interestingly, in Oger (Gen. Div.), ibid. at 219 , Molloy J. notes that the insurance policy under consideration in Oger was remarkably similar to the policy reviewed by the court in Oshawa Group Lid. v: Great American Insurance Co. (1982), 36 O.R. (2d) 424 (C.A.) [Oshawa]. However, in Oshawa, Lacourciere J.A., writing for the Courn. focused on the interpretation of the exclusion. mather than the identification doctrine (at 433-36). The issue of contractual interpretation will be dealt with in more depth in the discussion of Nesmoms Imdustrical. 2000 MBQB 66, 146 Man. R. (2d) 231, afT' 2000 MBCA 128, 150 Man. R. (2d) 296.

Ibid. al paras. 1-4.

thid. at para. 4.

Supra note 28.

libid. at para. 18.

lbid. at para. 12. The trial judge found that the employees "deliberately overstated the value of December 31, 1993 ending inventory by misrepresentation in the form of brass bars posing as gold dore bars": International Nesmont indusiriul Corp. v. Continental insurance Co. of Canada, 2000 BCSC 1136, 22 C.C.L.I. (3d) 31 at para. 16 [Nesmont Indhssrial (S.C.)]. Justice Southin in Nesmon Industrial (C.A.), supra note 28 at para. 12. described this as a "sophisticated form of salting."

The plaintiff had been sued by its American shareholders in the U.S. courts for issuing liraudulent finuncial statements. The plaintilf atlempled to recover under the insurance policy for the amounts that would be due from the U.S. proceedings. Both the trial judge and the Court of Appeal found that the policy, as a matter of contractual interpretation. did not cover this type of loss owing to the sharelwiders. For the trial court, see Nesmont Indesstrial (S.C.), ibid. at paras. 56, 72; for the Court of Appeal, sec ibid. at paras. 16-17. The sharcholder claim is unimportant for current purposes. This article focuses on the corporation's own claim for losses resulting from the alleged employer fraud. 
Supreme Court held that the identification doctrine applied and that the fraudulent employees were directing minds of the corporation. However, under the summary trial procedure used in the case, there was no evidence as to the applicability, or lack thereof, of the defences. Although the Court supported the concept of the identification doctrine, it did not have a sufficient foundation to know whether it applied on the facts. The Court of Appeal had no such difficulty. Justice Southin held:

\begin{abstract}
An insurer, as the proferens, ought to take particular carc to draft any exclusion so it is plain of meaning. I have asked myself this question: Would a reasonuble director of a corporation appreciule from rending this exclusion that a defalcation by the Chief Executive Oflicer who was also a director was nol covered? I think not. Why [would a corporation] have such a policy if it excludes top management? If this insurer intended to exclude top management, it could easily have written "by any insured or partner or, if the insured is a corporation, by any person or persons whatever their title who is or are the directing minds of the corporation". 51
\end{abstract}

It appears that there are two basic problems with Southin J.A.'s analysis: the first deals directly with the issue of contractual interpretation; the second deals with the peculiarities of the law of insurance.

On the first point, the Court of Appeal held that the contractual exclusion was not intended to invoke the identification doctrine. This conclusion is based on one canon of contractual interpretation, that is, contra proferentem. In other words, ambiguities should be resolved against the writer of the contract, in this case, the insurer ${ }^{52}$ Thus, the fact that the fraudulent employee would otherwise be a directing mind of the corporation is irrelevant to the issue of recovery under the policy.

However there is another canon of interpretation that is also invoked here: the Court's obligation to give meaning to the words chosen by the parties. If the contractual exclusion, which excludes coverage for the fraudulent actions of the insured, does not invoke the identification doctrine, when would the contractual exclusion apply in the case of a corporate insured? If the identification doctrine does not apply, how is it possible for the corporation itself (as opposed to its agents) to commit fraud, so as to make the exclusion relevant? Put another way, the Court is clearly correct in asserting that the parties could have improved the contractual drafting to make clear that the identification doctrine was meant to apply in these circumstances. Nonetheless, an important issue still remains to be resolved: while the parties may not have used the best drafting, it is still the obligation of the Court to make a reasonable interpretation of the contract, and thereby give effect to its terms. As the Alberta Court of Appeal put it in Scurry-Ruinbow Oil Lid. v. Kasha:

3 See Zurich Life Insurumce Co of Canada s. Davies, [1981] 2 S.C.R. 670, Laskin. C.J.C., for the Court, held that any ambiguities in a contract of insurance, being a contract of adhesion. are to be construed against the insurer. For a case that views this principle as "trite law" see Re Camoda 3000 lnc. (2002), 35 C.B.R. (4th) 37 at para. 19 (Ont. Sup. Ct.). 
The objective is to discover and give effect to the real intention of the parties. That intention must be found, in the first instance, in the operative words of the document, read as a whole, giving meaning to every provision if that is possible. ${ }^{53}$

By reading the exclusionary clause as it did, the British Columbia Court of Appeal in Nesmont Industria/ has essentially said that the clause does not apply to corporations al all. To read the contract in this way is to say that this clause, as between these parties, is entirely meaningless, given that the insured is a corporation. As such, a tension results: on the one hand, the Court is quite correct that contra proferentem seems to apply here; however, in applying it, the Court makes the clause meaningless. While these two maxims are often applied in tandem to justify a result in a given case, ${ }^{54}$ what should happen when the application of the two maxims leads to contradictory results? The Court of Appeal in Nesmont Industrial does not deal with this problem of contractual interpretation at all; it simply ignores the conflict between the two canons of contractual interpretation, and points to one, contra proferentem, as being capable of resolving of the issue before it. We are left with no guidance as to why contra proferenem should prevail over this obligation to give effect to the words chosen to express the intentions of the parties, or any other canon of interpretation for that matter. ${ }^{s s}$

The second point is perhaps of even greater importance than the first. Insurance law takes seriously the concept that the beneficiary must have "clean hands" in making the claim. The Latin maxim ex turpi causa non oritur actio is well established in the law of insurance. Justice McLachlin (as she then was) acknowledged as much in Hall v. Heberl, when, speaking for the majority, she held:

The power expressed in the maxim ex turpi causa mon oritur actio linds its roots in the insistence of the courts that the judicial process not be used for abusive, illegal purposes. Thus Professor Gibson, in "Comment: Illegality of Plaintifrs Conduct as a Defence" (1969), 47 Can. Bar Rev. 89, at p. 89, writes:

Few would quarrel with the proposition that a man who murders his wealthy aunt should not be allowed to receive the proceeds of her life insurance as beneficiary, or that two robbers who disagree over the division of the spoils would not be allowed to settle their dispute in a court of law. It was to deal with flagram abuses like these that English courts developed the principle expressed in the maxim: ex turpi causa non oritur actio - no right of action arises from a base conse.

See Tom F. Mayson, "The Use of Extrinsic Evidence in the Interpretation of Written Agreements in Alberta" (2004) 42 Alta. L. Rev. 499 at 51 I. Interestingly, Mayson specifically mentions jurisprudence with respect to contracts of insuranec that $m i g h t$ have also assisted the Court of Appeal to reach its result in Nesmon Indhssrial (at SI 1-12). Nonetheless, the Court of Appeal referred to none of the other interpretive rules mentioned by Mayson, which were drawn from the Supreme Court of Canada's decisions in both Reid Crowther \& Partners LAd. v. Simcoe \& Erie General Insurance Co., [1993] 1 S.C.R. 252 at 269 and Brissette Estate v. Westbury Life Insurance Co.: Brisente Estate v. Crown Life Insurance Co., [1992] 3 S.C.R. 87 at 92-93. Furthermore, Mayson also points out that contra proferemem is only to apply where, among other things. "all other rules of contractual interpretation have failed" (at $5 / 2$ ).

ss For another example where the Court construed a similar clause against the insurer so as to negate the exclusion, see Oshania, supra note 43. 
The use of the doctrine of ex mrpi causo to prevent abuse and misuse of the judicial process is well established in contract law and insurance law, where it provokes little controversy. 57

This last statement shows that the doctrine of ex turpi causa non oritur actio is a basic element of public policy. It holds that a criminal should not be allowed to benefit by his criminal act. ${ }^{88}$ That being so, how does this basic element of public policy apply in the corporate context? If the analysis of the British Columbia Court of Appeal in Nesmont Industrial is correct, the only possible answer is that it can never apply to a corporation. After all, the corporation can only commit a mens rea crime, through the common law identification doctrine or its legislative counterpart. Yet the doctrine's application is dependent, according to the Court of Appeal, on contractual interpretation. If the contractual interpretation supports the application of the identification doctrine, then recovery is barred by the contract. If the interpretation of the contract does not support the application of the doctrine, then arguably the wrongdoing is not that of the corporation. Either way, the issue of public policy never arises. Surely, the application of fundamental issues of public policy should not be subservient to the interpretation of contracts.

This is not to say that the Ontario Court of Appeal's result in Nesmont Industrial might not have been justified. If, in fact, the Chief Executive Officer was taking money from his employer, as the Court of Appeal seems to believe, ${ }^{34}$ then the defence of fraud on the corporation would apply, and the acts of the defrauding employee would not be attributed to the corporation. This conclusion though would be based not on contractual interpretation of the relevant insurance policy, but rather, on the fact that the bounds of the identification doctrine were exceeded. The trial judge felt that there was an insufficient factual record on which to make a determination of whether the defences applied; the Court of Appeal sidestepped this issue entirely. ${ }^{611}$

Let us briefly examine this issue from the point of view of a case discussed earlier, namely Clarkson v. Canadian Indemmity Co ${ }^{61}$ Interestingly, the issues dealt with in Clarkson are similar to those in Nesmont Industrial. Nonetheless, the latter case makes no mention of the former. What would happen if the Ontario Court of Appeal were deciding Clarkson today? The question asked by the British Columbia Court of Appeal in Nesmont Industrial ("Why have such a policy if it excludes top management?"62) is as equally applicable to the facts of Clarkson as it is to those of Nesmont Industrial. So, if we assume that Clarkson were decided after the decision in Nesmon Indtustrial rather than before it, the result in Clarkson would have changed. Based on the reasoning of Southin J.A. in the British Columbia Court of Appeal, the corporation in Clarkson would have recovered under the insurance policy even though none of the three aforementioned traditional defences to the identification doctrine would have applied. So, even though the application of the identification doctrine would likely not have altered the result in Nesmont Industrial itself, the analysis used, if it were

Ibid. at 170-71 [emphasis in original].

Denis Boivin, Insurance Lan, Essentials of Canadian Law (Tomnto: Inwin Law, 2004) at 209-12.

Nesmont Industrial (C.A.), supro note 28 at para. 25.

thid.

Stupra note 30.

Nesmont Industrial (C.A.), supra note 28 at para. 25. 
adopted in the subsequent jurisprudence, may have had a fundamental impact on the results in those cases.

\title{
B. OUTSIDE THE INSURANCE CONTEXT
}

Outside of the insurance context, there has been relatively little use of the identification doctrine as a defence to civil liability. Still, there are at least three recent non-insurance cases of note.

In Boma Manufacturing Lid. v. Canadian Imperial Bank of Commerce, ${ }^{63}$ the appellant corporation had been defrauded by its bookkeeper, who had written and signed cheques to various people to whom the corporation did not owe money. The bookkeeper cashed the cheques into one of three of her own bank accounts, having fraudulently endorsed some of the cheques and fraudulently obtained the signature of her supervisor on others. Over approximately five years, 155 cheques were written, totaling over $\$ 91,000{ }^{64}$ While there were a number of issues in the case," the judgment of the Supreme Court of Canada in Boma mentions "intention" in terms of the "fictitious payee" section of the federal Bills of Exchange Act: "[w]here the payee is a fictitious or non-existing person, the bill may be treated as payable to bearer."

In order to determine the liability of the bank for an endorsed cheque, as well as the defence provided for under this section, the intention of the drawer is critical. ${ }^{67}$ Justice lacobucci held:

\footnotetext{
It is the intention of the drawer, nol the signatory of the cheque, that is relevant ... Alm is not the drawer because she cannot be said to be the directing mind of the corponte appellants; she simply had signing authorily within limited circumstances. The relevant intention in this case is that of the drawer, the appellant companies. In the absence of Alm's fraud, they would have been liable, not Alm, if the cheques had been validly issued and were subsequently dishonoured by the drawee. ${ }^{68}$
}

Justice lacobucci continued later in his judgment to define the point at issue in the appeal: "The key issue is whether the drawer intended the payees to receive payment, which itself raises the question of who the drawer is. Can Donna Alm's intention be imputed to the appellants?" rogue bookkeeper was the directing mind of the corporation (he refers to both "directing mind"70 and "guiding minds"1) with respect to dealing with these cheques. Since the bookkeeper was not a guiding mind of the corporate employer, her intention with respect to these cheques was not the intention of the corporate drawer. ${ }^{72}$ Due to the interpretation of the

\author{
[1996] 3 S.C.R. 727 [Boma]. \\ lbid. at paras. 2-10. \\ lhid. al paras, 27-28. \\ R.S.C. 1985, c. B-4, s. 20(5). \\ Boma, supra nole 63 at paras. $44-46$. \\ lbid. at para. 40. \\ Ibid al para. 53. \\ lbid. at para. 40. \\ libid. at para. 56. \\ lbid. at para. 84 .
}


rules contained in the Bills of Exchange Act, this led to the conclusion that the respondent bank was required to make good the loss suffered by the plaintiff corporation. ${ }^{73}$ Unfortunately, because the bookkeeper did not pass the threshold test of being a directing mind of the corporation, the Court in Boma did not consider whether the fraud on the corporation defence would have applied in these circumstances.

However, this issue did arise the next time that the Supreme Court of Canada examined the issue of the identification doctrine in a civil context. In 373409 Alberta Lid. (Receiver of) v. Bank of Montreal, ${ }^{\text {it }}$ the Supreme Court dealt with a case where an individual took a cheque made out to a company of which the individual was the sole director and shareholder (Company 1), and deposited it into the account of another company of which the individual was again the sole director and shareholder (Company 2). Company 1 then went bankrupt, and the receiver sued the bank in conversion. The major issue in the case was whether Company 1 authorized the deposit of the cheque into the account of Company 2. If so, then the bank was not liable in conversion. If not, the bank would be so liable. ${ }^{75}$ The Court held that since the individual was the directing mind of Company 1 , his decision to deposit the cheque in the account of Company 2, known as Legacy, was the decision of Company 1 , known as 373409. ${ }^{76}$ The Court held that, given that the individual in question was the sole shareholder, director, and officer of the corporation at issue, the defence of fraud on the corporation simply did not apply. On this point, Major J. held:

In Canadian Dredge \& Dock Co. v. The Queen, it was held ... that where a criminal act "is totally in fraud of the corporate employer and where the act is intended to and does result in benefit exclusively to the employee-manager", that act cannot be attributed to the corporation. In this appeal. Lakusta's diversion of money from 373409 to Legacy may very well have been wrongful vis-i-vis the corporation's creditors. However, Lakusta's action was not in fraud of the corporation itself. Since Lakusta directed the funds into Legacy's account with the full authorization of 373409 's sole shareholder and director, being himself, that action was not fraud in respect of $373409 .^{17}$

As such, the deposit was authorized, and the bank was not liable in conversion. ${ }^{78}$

Ibid. at para. 87. Interestingly, in the dissent written by La Forest J. (McLachlin J., as she then was. concurring), objection is taken to the majority"s position that the intention of the fraudulent employec could not be attributed to the corporate employer (ibid. at para. 100). This disagreement is based, not on the identification doctrine, but rather on principles of agency (ibid. at paras. 100-102). 2002 SCC 81, [2002] 4 S.C.R. 312 [373409].

Ibid. at para. 12.

Ibid. at para. 20.

Ihid. at para. 22 [references omitted].

Ibid, at para. 24. 
Assuming that a discussion of the identification doctrine is appropriate on these facts, ${ }^{79}$ my question is a simple one: Why is the fraud on the corporation defence inapplicable here? With due respect to the Supreme Court of Canada, this was precisely the situation in which the defence of fraud on the corporation was meant to be applied.

It is important to remember that the identification doctrine is a judicial invention, designed to give meaning to a legal concept, that is, the separate personality of the corporation. ${ }^{80} \mathrm{At}$ least one of the primary reasons for the adoption of the identification doctrine in criminal law was the desire of the judiciary to not have a significant amount of commercial and philanthropic activity outside the reach of the criminal law..$^{81}$ The attribution of personhood to a corporation in turn necessitates a mechanism to give that person a mental state. Regardless of whether personality is real or fictional, this person has no independently functioning brain through which it can form a mental state. Since so many areas of our law depend on mental states, the law must therefore attribute a mental state to the corporation. A corporation cannot protect its own interests; it must rely on others to protect it. ${ }^{82}$ It is

I have serious reservations about the consideration of the identification doctrine by the Court at all in this case. One way to think about this is as lollows: the identification doctrine is generally concerned with mental states. The depositing of a cheque is an action, without a particular mental state attached to it. If any mental state is relevant at all, it is that of the drawer: see Boma, stupra note 63 at para. 40 . On the facts of 373409 , the intention of the drawer is irrelevant, because the drawer intended to pay off a debt to the corporate payee (373409); therefore, this seems more akin to the making of a contract. The making of a contract is determined on completely scparate principles, namely those of agency: see Frecman \& Lockyer v. Buckhursi Park Properties (Mangal) Lid., [1964] 2 Q.B. 480 (C.A.). An individual can have the authorily to undertake certain actions on behalf of the corporation without ever being the "embodiment of the company" (see Tesco. Supermarkets LAd. v. Naltrass, [1972] A.C. 153 (H.L.) at 170 [Tesco]), that is to say withoul ever being a directing mind of the corporation. Therefore, the Supreme Coun of Canada's use of identification doctrine is confusing. To add to the confusion, Major J., for the Court, uses terminology which is, at best, ambiguous. In fact, Major J. specifically uses the terms "agent" and "authority" in numerous places in the judgment: see e.g. references to "authority" at paras. 1, 6 and to "agent" at paras. 20,23. The case is either to be decided on the principles of the law of agency (as the use of the terms "agent" and "authority" would suggest). or based on the identification doctrine, but the two are independent of each other. Therefore, in my view, it should be one or the other of agency principles or the identification doctrine, but not both.

I have carcfully avoided the term "legal fiction" to describe the personality of the corporation here. I recognize that there is still some debale between those who claim that the personality of the corporation is a reality, and those who maintain that the personality of a corporation is nothing more than a legal fiction. Still others claim that tle personality is neither reality, nor total fiction, but instead a concession of the state to the needs of commerce. For a more thorough discussion of this issue, see Christopher $C$. Nicholls, Corporate Law (Toronto: Fmond Montgomery Publications, 2005) at 17-24. This is not the appropriate fonum to attempt to weigh in on this fundamental debale. I therefore leave the issue for another day.

See Cunadian Dredge, supra nole I at para. 66; R. v. Church of Scientology (1997). 33 O.R. (3d) 65 at I36 (C.A.).

In fact, the fiduciary duties placed on directors and officers of a corporation are specifically designed to protecl "the best interests of the corporation": $C B C A$, supra note 10, s. 122(1)(a). Some might suggest that the idea that the corporation cannol do anything truly "on its own" undermines the very concept of separate legal personality for comorations. With all due respect for those who hold this view, I would disagres. As important as separate legal personality is to the law of corporations (and it is very important), it must not be puslied beyond its intended limits. Separate legal personality does not mean that we should ignore the reality that this person (the corporation) is vulnerable to abuse by other people (those who have effective control of corporate operations). The prospect of such abuse - and the measures designed to prevent its ill effects, such as fiduciary duty, and limiting the polential application of the identification doctrine as opposed to expanding it - does not run counter to separate legal personality. On the contrary, it only serves to heighten its importance. 
unsurprising, then, that when the law needs to attribute a mental state to a corporation, it chooses someone with a managerial connection to the corporation who is supposed to serve the corporation's interests.

However, human nature being what it is, a fiduciary can forget his or her duties to the corporation and victimize the corporation in order to serve his or her personal goals. When this happens, the connection and community of interest between the senior officer as fiduciary on the one hand, and the corporation as beneficiary on the other, is lost. This connection is essential to the application of the identification doctrine. If the mental state of an individual is to be attributed to the corporation, surely that mental state should not be one of an individual who is stealing from the corporation.

That is not to say Major J. necessarily disagrees with this analysis of the justification for the fraud on the corporation defence. However, there is one notable caveat. Justice Major does not believe that the defence applies to a single-shareholder, single-director, singleofficer corporation. But many modern corporations are "one-person" corporations. Thus, the legislature seems to have made a conscious choice to allow this type of corporation. ${ }^{\times 3} \mathrm{Having}$ made this policy choice at the legislative level, it seems problematic for judges, even those of the Supreme Court of Canada, to say that by virtue of being a one-person corporation, one is not entitled to the same legal protections (namely, the fraud on the corporation defence) as are afforded to other corporations.

Corporate law is full of checks and balances. According to the $C B C A$, those who have control of the corporation's fortunes owe duties designed to protect the corporation. ${ }^{\text {st }}$ Similarly, shareholders elect the directors. ${ }^{85}$ Directors are in turn empowered to "manage, or supervise the management of, the business and affairs" of the corporation. ${ }^{86}$ Directors also appoint the officers of the corporation and delegate powers to those officers. ${ }^{87}$ When different people wear these various "hats" within the corporation, there is at least the possibility of supervision and oversight by one group of the others involved in the corporation.

Where, however, a single person plays all three roles - shareholder, director, and officer - and that person has decided to victimize the corporation, all of these devices are suddenly stripped away from the protection of the corporation. The individual is obviously unconcerned with his or her fiduciary duty to the corporation; otherwise, he or she would not defraud the corporation. The idea of a person in all three roles destroys any realistic chance of supervision by others within the corporate hierarchy, because there is no hicrarchy to speak of. In a sole-shareholder corporation, the sole shareholder can generally waive the requirement for an annual audit of the financial statements. ${ }^{\mathrm{Bg}}$ This lack of supervision may

This is all the more obvious when one considers that under the Companies Act, 1862 (U.K.), 25 \& 26 , Viet., c. 89, s. 6, seven people had to sign to be subseribers for shares for the memorandum of association to form the corporation. Sec Salomon, stpra nole 10 at 38.

Jbid., s. $106(3)$.

Ihid., s. 102(1).

Jbid., s. 121.

Jbid., ss. 162-63. 
actually provide an incentive for misbehaviour. After all, as the probability of being caught decreases, the deterrent value of the sanction for the misbehaviour decreases as well.

For example, assume that the sanction for certain behaviour is $\$ 1,000$. Assume further that the odds of getting caught are 80 percent. Assume also that the individual committed the misbehaviour ten times. The misbehaviour would cost the individual $\$ 8,000$. Now, assume that the only variable that changes is the likelihood of getting caught. Alter this percentage from 80 percent to 30 percent. With this change alone, the cost of the misbehaviour for the individual is lowered from $\$ 8,000$ to $\$ 3,000$. If there is any deterrence value at all in the monetary sanction, it is clearly less when the likelihood of discovery of misbehaviour is reduced. Supervision by others deters potential employee wrongdoing. The deterrence offered by meaningful supervision does not exist in a single-shareholder, single-director, single-officer corporation.

The defences to the application of the identification doctrine, notably the fraud on the corporation defence, would provide a layer of protection to the separate legal person of the corporation when another person (the individual who would otherwise be the directing mind of the corporation) tries to take advantage of his or her power vis-à-vis the corporation. Justice Major's analysis in 373409 removes the protection of the defences referred to earlier from a corporation when it needs that protection most.

This is particularly so, given that in many cases, the wrongdoing of the shareholder/ director/officer is not discovered until after the individual is no longer in control of the corporation's fortunes. The 373409 decision is a prime example of this type of circumstance. The rogue (Lakustra) caused the cheque originally payable to 373409 to be placed in the account of another company controlled by him, and then later withdrew the funds. ${ }^{89}$ By the time the lawsuit ended up before the Supreme Court of Canada however, the first company had been placed in liquidation and turned over to Ernst \& Young Inc. as Receiver-Manager." The rogue was not before the Court in the appeal. ${ }^{91}$ Therefore, the contest is between the creditors of 373409 , represented by the receiver-manager, and the bank: the rogue is not involved. Yet, the creditors pay the economic price for his wrongdoing. If the rogue were still available as a defendant, and sufficiently solvent to pay a judgment against him, after the receiver-manager was appointed, the corporation could sue for, among other causes of action, breach of fiduciary duty. Why should the position of the rogue somehow put the burden of the loss on the corporation, or, perhaps more accurately in this case, its creditors? After all, the corporation could not protect itself against the rogue who was its sole director, sole officer, and sole shareholder.

One final argument will perhaps assist to make the point here. The corporation is clearly the victim of a breach of fiduciary duty by the rogue. ${ }^{92}$ Yet, for the purposes of the

373409 , supra note 74 at para. 3.

Ibid. at paras. 2. 4.

373409 Alheria lid. (Receiver of v. Bank of Montreal, 2001 ABCA 76, 198 D.L.R. (4th) 40.

Clearly, diverting funds away from the corporation to another person cannot be in the "best interests of the corporation," as required by s. 122(1)(a) of the CBCA, supra note 10. Even though the funds ended up in the hands of a rogue, who is also a shareholder (see 373409, supra note 74 at para. 3), this is still a breach of fiduciary duty. Under $\mathbf{s}$. 120 of the $C B C A$, if a director of the corporation is interested in a 
identification doctrine, according to Major $\mathrm{J}$. in 373409 , the corporation is also responsible for the very actions and mental state of its agent (the rogue), which made it a victim. In this sense, the corporation is simultaneously perpetrator and victim. Logically, how can this be? If the application of the identification doctrine creates a logical inconsistency such as this, perhaps it is an indication that it would be inappropriate to apply the doctrine in these circumstances. $^{93}$

Finally, one last case is worthy of discussion. In J.C. Creations Ltd. v. Vancouver City Savings Credit Union, ${ }^{94}$ the facts were somewhat similar to those in both $373409^{45}$ and Boma. ${ }^{96}$ In J.C. Creations, Southworth, an accountant employed by the plaintiff corporation J.C. Creations Lid., was being dishonest. ${ }^{97}$ Southworth had placed cheques with respect to which the corporation was a payee into an account of a second corporation controlled by Southworth. ${ }^{98}$ Relying on both 373409 and Boma, ${ }^{99}$ the British Columbia Court of Appeal held that Southworth had no authority to deposit cheques. ${ }^{100}$

This case is interesting because the drawers of the cheques at issue were third parties. They were debtors who owed money to the plaintiff. J.C. Creations Ltd. was the payee of the cheques. ${ }^{10 \prime}$ As outlined in Boma, if a mental state is relevant at all, it is the mental state of the drawer to be considered. ${ }^{102}$ Therefore, even though the identification doctrine may have been relevant here, ${ }^{103}$ the case was determining the intention of the wrong corporation, that

material contract of the corporation, then disclosure in a timely manner is required and the director cannot vote to approve the transaction: see ss. 120(1)-(2), (5). While it may be possible to approve such a transaction as a shureholder under $\mathrm{s.} 120(7.1)$ of the $C B C A$, there is no evidence in the case as described by the Supreme Court of Canada that any of these corporate formalities were in fact followed. Given that (1) neither the Alberta Court ol Appeal nor the Supreme Court of Canada mentioned the use of this mechanism on the facts, and (2) conversion is the wrongful interference with the chattels of another, the use of these legitimizing mechanisms is unlikely here. If the proper corporate procedures had been followed. money could have been removed lawfully from the coporation and conversion never would have arisen on the facts.

For further discussion of possible resolutions when the application of the identification doctrine might be inappropriate, see Pan V.D. below.

2004 BCCA 107, 24 B.C.L.R. (4th) 280 [J.C. Creations].

Supra note 74.

Supra note 63.

J.C. Crecalions, stupra note 94 at para. 2.

ibid. at para. 6.

Ibid. at paras. 12-13.

Ibid. at para. 15. Interestingly, the basis for the decision in this case is unclear. On the one hand, Hall J.A. relies on Boma and 373409 , cases which explicitly rely on the identification doctrine to justify their results. However, Hall J.A. does not specifically say that the fraudulent employee is not a directing mind of the corporation, but relies instead on the cmployee's authority with respect to dealing with cheques. This would seem to suggest that the Court is concemed with agency principles. Finally, the Court rejects the invitation of the respondent to consider the minority judgment in Boma: see J.C. Creations, ibid. at para. 15. However, this refusal by the Court is not explicitly based on the incorrectness of the approach put forward by La Forest J.'s dissent in Boma, but rather on the lack of evidence to support a conclusion of authority of the bookkeeper on the lacts of the case before the British Columbia Court of Appeal in J.C. Creations, ibid. at para. 15. Therefore, this refusal would seem to suggest that the Court might have considered a defence based on the principles of agency if the facts would have supponed such a defence. As the Court of Appeal put it: "These cheques should have been deposited into the Creations account at the Toronto Dominion Bank" (ihid. at para. 5).

Boma, supra note 63 at para. 40.

This assumes that the case was in fact decided by the application of the identification theory at all. Sec supra note 100 and accompanying text. 
is, the payee, instead of the drawer as required by decision of the Supreme Court of Canada in Boma.

\section{SUMMARY}

First, Boma provides an example of where the individual at issue was not sufficiently senior to be a directing mind. Therefore, the corporation was not held responsible for the mental state of the individual. Second, Clarkson illustrates a situation where the identification doctrine was applied without any defences being applicable. Third, Nesmont Industrial demonstrates a circumstance where the Court indicated that the wording of a contract of insurance can supplant the application of the identification doctrine, if the wording of the contract is less than clear. Finally, J.C. Creations offers an example of where the Court, according to binding precedent (Boma) applied the identification doctrine to the wrong corporation. In the same case, whether the Court uses the doctrine at all is not terribly clear. The cases cited by the Court in J.C. Creations to justify its conclusions appear to invoke the identification doctrine, but other wording used by the Court seems to suggest the use of agency principles.

With respect to defences, the cases are also unclear on some points. Eastern Chrysler Plymouth lnc. shows that even though the identification doctrine applied prima facie to the facts at hand, the limits of the doctrine can be exceeded because the individual was acting outside the scope of authority at the time that the actions were taken. Similarly, Oger illustrates a situation where the employees were acting in fraud of the corporation, thereby demonstrating another way that the identification doctrine can be exceeded. In 373409 , the Supreme Court of Canada held that the defence of fraud on the corporation did not apply to certain corporations.

As this review demonstrates, the judicial analyses of the identification doctrine in the civil context are, at best, highly fact-dependent. ${ }^{104}$ At worst, the decisions of various courts considered above are poorly articulated, unclear, and maybe even downright confusing to anyone not wearing judicial robes. Perhaps then, the legislative change detailed below provides an ideal opportunity to reconsider the progress of this area of law.

Hart itself is a non-insurance case that falls into the same category as Clarkson. That is, the identification doctrine was applied, without any defences being applicable on the facts. It is clear from the reasons for judgment that the respondent asked the Supreme Court of British Columbia to consider the broader policy implications of the application of the doctrine. However, the Court was dismissive of the respondent's policy arguments, holding that the Supreme Court of Canada decision in Canadian Dredge had already folded in all policy considerations, amongst other reasons. ${ }^{105}$ The decision, therefore, is an example of the

Remember that the conclusion in Boma was based on a fraudulent employee writing cheques drawn on the employer's account that the employee subsequently cashed for her own benefit. Meanwhile, in both 373409 and J.C. Creations, the fraudulent employee cashed cheques of which the employer was the payee. According to Boma, this distinction is essential, although neither of the subsequent cases specifically avert to it. 
application of the doctrine without meaningful consideration of the policy underlying it. As will be outlined below, such a policy-oriented approach is an essential component of the application of the doctrine in civil cases.

\section{The IMPORTANANCE OF THE HART DECISION}

So, if the direction of the courts in this area of law is fairly inconsistent, and Harf is another example of this, the question becomes why this case warrants an academic article. As indicated earlier, the test for the identification doctrine has historically been the same regardless of the context in which it is used, be it as a sword against the corporation in criminal courts (Canadian Dredge) or in civil contexts (Rhone) or as a shield against civil liability (Hart). But, due to recent legislative changes, this may no longer be the case.

\section{A. STATUTORY REFORM ${ }^{106}$}

On 31 March 2004, An Act to Amend the Criminal Code (criminal liability of organizations) ${ }^{107}$ came into force. ${ }^{108}$ The statute makes five important changes to the law of corporate criminal ljability. First, for the purposes of the criminal law, a directing mind, as defined above ${ }^{109}$ is no longer necessary to establish corporate liability. Rather, a "senior officer," as defined by the statute, is all that is required. A senior officer includes everyone who would be considered a directing mind under the common law. But, lower-ranking corporate officials are also senior officers. Anyone who has responsibility for "managing an important aspect" of the corporation's activities is also a senior officer. ${ }^{10}$ Therefore, the amending legislation in this sense, makes it easier to use the identification doctrine as a sword against the corporation in the criminal context, in that the acts of mid-level managers can render the corporation liable.

Second, under the common law, a person can be a directing mind for one purpose without being a directing mind for other purposes. If the individual has policy-setting authority in a given area, then in that area, the person is a directing mind. ${ }^{\prime \prime}$ If the person committed a crime using that area of the corporation to commit it, the corporation could be liable for that crime. But, if that same person were to use another area of the same corporation in which the he did not have policy-setting authority to commit the same crime, the person is not a directing mind. If the vice-president of finance dictates that the financial statements of the corporation are to be altered, for example, to cover a fraud, then the action was taken by a directing mind acting within the scope of policy-setting authority. But if the vice-president of marketing, who would have policy-setting authority in marketing but not in finance, took the same action, then at common law, the vice-president of marketing would not be a

The issues considered in this section are covered in more detail in Darcy L. MacPherson, "Extending Corporate Criminal Liability?: Some Thoughts on Bill C-45" (2004) 30 Man. L.J. 253 [MacPherson, "Extending Corporate Criminal Liability?"].

S.C. 2003, c. 21 [Act to Amend the Criminal Code].

This is fixed as the date on which most of the operative provisions of the statute came into force. Sec Privy Council Minute 2004-90 (16 February 2004). One section of the statule came into force upon assent.

Rhône, supra note 9 at 521.

Criminal Code, R.S.C. 1985, c. C-46, s. 2 [Criminal Code].

Rhöne, supra note 9 at 521. 
directing mind in finance. Thus, in this scenario, under the common law, the corporation is not liable. However, under the Act to Amend the Criminal Code, if a senior officer becomes aware of potential wrongdoing by anyone associated with the corporation, and does not take "all reasonable measures" to prevent it, the corporation could be liable. ${ }^{12}$ This is true even if the senior officer has no responsibility whatsoever for the operational area of the corporation in which the crime occurred.

Third, under the common law, generally, the directing mind had to have committed the underlying offence before the corporation could be convicted. ${ }^{113}$ Under the statute however, it is possible to convict the corporation without convicting the senior officer, and even without the senior officer having committed any crime known to Canadian law. ${ }^{114}$ As mentioned above, if the senior officer knows that anyone associated with the corporation is about to commit a crime and the senior officer does not take all reasonable steps to prevent it, the corporation can be convicted, but not the senior officer. ${ }^{115}$

Fourth, at common law, in order to hold a corporation liable for negligence-based crimes, the criminal negligence had to be the responsibility of one individual alone. ${ }^{16}$ Under the statute though, with respect to crimes in which criminal negligence must be proven by the prosecution, the courts are entitled to view the action of the senior officers collectively. ${ }^{117}$ This means that if one senior officer makes a decision that is negligent ${ }^{118}$ but does not meet

112 Criminal Code, supra note 110, s. 22.2(c).

11. Canadian Dredge, supra note 1 at 682 . Two points must be made herc. First, even though the directing mind may have committed the offence, this does not mean that the directing mind will necessarily be charged and tried, let alone convicted of the offence: the state may choose to proceed against the corporation without any action against the directing mind. In this sense, the liability of the corporation is independent of that of the directing mind. The statute does not alter this reality. Second, there are those who might claim that Estey J.'s statement that "the actions of the employee (who must generally be liable himsel/)" is in ertor (at 682) [emphasis added]. I tend to disagree with those who might take issue with this statement. As 1 read his reasons for judgment on behalf of the Court, Estey J. was simply making the point that, under the identification doctrine at common law, it would be rare that the circumstances would be such that the corporation could be convicted of a crime when there was no individual who had also committed the underlying offence. If 1 am right that this is the message that Estey J. intended to convey, then I have absolutely no quarrel with it; in lact, I would argue that he is quite correct. However, this is not the forum to resolve this dispute. Given the statutory modilications delailed above, the need to resolve this issue is significantly less pressing than previously, since $\mathbf{s}$. 22.2(c) of the Criminal Code, ibid, clearly changes the law in this regard, in the criminal sphere. Nonctheless, this does not mean that Estey J.'s comment is completely irrelevant. Until the civil application of the identification is harmonized with its criminal counterpart, the issue is nor totally moot. In any event, this debate (or at least any substantive contribution that I might choose to make to it) will have to wait for another day. Criminal Code, ibid., s. 22.2(c).

lbid.

Attorney-General's Reference (No. 2 of 1999), [2000] Q.B. 796 (C.A) at 813 [Attorney-General's Reference].

117 Criminal Code, supra note 110, s. 22.1.

118 The term "careless" might also be applicable here. However, several factors cause me to set aside the term. First, "carcless" does not have a precise legal meaning; "negligence," on the other hand, has quite precise meanings in the conlexts of both the civil and the criminal law. Second, carelessness in the widest sense is not synonomous with negligence, in the sense of the word as used in either the civil or the criminal law. For example, one can be careless in leaving one's car door ajar. Until some damage results from this carelessness, however, there is no negligence. Third, the meanings of the term are quitc different depending on the context, be it civil or criminal. This explains the need for the term "criminal negligence," and its specific definition in the Criminal Code. Thus, negligence seems a more appropriate 
the standard for criminal negligence, 114 and another senior officer makes a decision, which is again negligent but not so far below the reasonableness standard as to be criminal, the corporation may still be convicted of the offence. It is the cumulative effect of the two decisions, even though they are made by different people, that is judged in aggregate to determine whether the corporation is criminally liable on the higher standard of criminal negligence.

Therefore, in these four ways the amending statute makes it easier to use the identification doctrine as a sword against the corporation in the criminal context, in that the acts of midlevel managers can render the corporation liable for mens rea offences under the Criminal Code.

However, the fifth change to the common law made by statute actually makes it more difficult - in one respect - to convict the corporation under the statute than it was at common law. Under the common law version of the identification doctrine, the prosecution needed only to prove that the actions of the directing mind were either by design or result, partly for the benefit of the corporation. Under the statute, on the other hand, the result of an unintended benefit is not sufficient: proof of intention to confer a benelit on the corporation is necessary to convict the corporation. Ultimately, in different ways, the statute makes it both easier and more difficult successfully to prosecute a corporation criminally.

\section{B. Three Rationales in Favour of HaRmonization}

For reasons based on the division of powers, ${ }^{120}$ the law of torts is not directly affected by the statutory shin in the Criminal Code. The common law remains in place for torts, whether it is used as a sword or as a shield. To be clear, Hart was decided before the amending statute came into force. As a result, it is not suggested that the result in the case should have taken the statute into account. The question that is raised by Hart (thanks in large part to its timing just prior to the coming into force of the amending statute) is whether the common law should continue as it has with respect to the use of the identification doctrine in tort, or, altematively, whether the common law should reflect the changes brought about in the statute.

In my view, the latter option is preferable. At least three reasons justify this result. The first is historical. As mentioned at the beginning of this article, the identification doctrine received its first enunciation in a case of civil liability. ${ }^{121}$ In the early criminal cases where the prosecution was using the identification doctrine as a sword, the judges drew explicitly from the earlier civil case. ${ }^{122}$ The early cases on the identification doctrine as a shield clearly draw from the criminal side of the law. After citing the criminal case of St. Lawrence, ${ }^{123}$ the

term than simple carclessness.

Criminal Code, supra note 110, s. 219 (1).

120 Ton law generally lalls within exclusive provincial jurisdiction under s. 92(13), and criminal law falls within exclusive federal jurisdietion under s. 91 (27) of the Constirution Act, 867 (U.K.), 30 \& 31 Vict. c. 3, reprinted in R.S.C. 1985, App. I1, No. 5.

13i Lennard's Carrying, supra note 9.

122 Canadian Dredge, supra note 1 at 678-80; St. Lawrence, supra note 12 at 317-18.

123 St. Lawrence, ibid. 
trial judge in Clarkson v. Canadian Indemnity Co. held as follows: "[i]f criminal responsibility attaches to a corporation as a result of the actions of its directing minds in furtherance of a crime, I can see no justification for relieving a corporation of civil responsibility for the consequences of a dishonest policy implemented by the actions of those who control and direct the affairs of the corporation." 124 Thus, one of the explicit justifications for the use of the identification doctrine as a shield is that this is the natural outgrowth of the application of the same doctrine as a sword in the criminal sphere. Similarly, the rationale for its application as a sword in the criminal sphere arises from its use as a sword in private law, where mala fides of the corporation, rather than vicarious responsibility for the acts of its agents, had to be proven. ${ }^{123}$ Since, throughout the history of the doctrine, the civil and criminal sides have essentially been inextricably intertwined with one another, it would seem logical to me that the two should continue to operate together if possible.

But, reliance on historical arguments alone is likely insufficient. After all, one of the great strengths of the common law is the fact that it can adjust to changes to the social context in which the law operates. As Diplock L.J. explained: "The common law evolves not merely by breeding new principles but also, when they are full grown, by burying their ancestors." 126 In other words, a simple appeal to the fact that "this is the way we have always done it, and therefore, we should keep doing it this way" is not terribly convincing. Accordingly, there must be other reasons put forward to buttress the historical argument.

The second reason that the use of the identification doctrine as a defence to a civil action should be brought into line with the amending statute is policy-driven. The particular policy concem addressed in this section is judicial economy. There can be little doubt that the criminal and civil sides of the law can be invoked under the same facts. By having both criminal and civil liability decided under the same test, the parties involved may avoid the need for two trials, and instead be able to resolve the issue in a single proceeding. ${ }^{127}$

Perhaps an example would assist here. Assume that someone with operational responsibility for an area of corporate affairs committed a fraud by using the corporation as a vehicle designed to line the pockets of that individual. Furthermore, assume that the corporation has been prosecuted criminally for the commission of fraud, and that the victims of the fraud have also sued the corporation in civil court, secking damages for the tort of deceit, in a situation where vicarious liability is not available. ${ }^{128}$

124 Clarkson (H.C.J.), supra note 30 at 298.

12s Sec e.g. Canadian Dredge, supra note 1 at $713-14$; St. Lawrence, supra note 12 at 320.

126 Hong Kong Fir Shipping Co. LId. v. Kawasaki Kisen Kaisha Lid., [1962] 2 Q.B. 26 (C.A.) at 71.

127 To be clear, it is not suggested that eriminal prosecution and civil liability would actually be decided simultaneously. However, as will be seen below, if the lactual determination is made against one party in the first proceeding, this may alleviate the necessity for the second trial.

There is casc law lo suggest thut principles of vicarious liability may be applied even to intentional torts. Sec c.g. Buziey v. Curry, [1999] 2 S.C.R. 534 ut paras. 57-58, where the Supreme Court unanimously held that the applicntion of vicarious liability principles was approprinte in the case of intentional torts arising out of claims of sexual abuse. This was based on a review of both policy and principle. While this ease itself did not arise in the corporate context, as the employer was described as a non-profit organization, it refers to many cases involving the attempt (successful or not) to use vicarious liability principles against corporations in intentional tort eases. In one case of an ecelesiastical corporation, the Supreme Court of Canada based liability on both direct and vicarious grounds: see Joln Doe v. Bennett, 
Under the statute, the relevant questions to be answered at trial would include: (1) does the individual manage "an important aspect of the corporation's activities"?; 129 and (2) did the individual intend a benefit to the corporation? At common law, different questions would be asked. These would include: ( 1 ) does the individual have policy-setting authority within the corporation?; (2) does the policy-setting authority extend to the area in which the crime occurred?; and (3) was there a benefit to the corporation? To the extent that the questions to be answered are different, two different factual inquiries, that is, two trials, would be necessary. Two trials could potentially lead to inconsistent conclusions. For example, if the criminal trial held that the individual was responsible for managing an important aspect of the corporation's activities, and was thus a senior officer, this would entitle the criminal prosecution to succeed. But, without more, this is not necessarily sufficient to allow the civil action to succeed at trial. On the civil side, these findings in the criminal trial do not resolve the issues of whether the individual in question had policy-setting authority or the scope of that authority, if any. In fact, it is possible that even though the individual has significant operational authority, he or she lacked the policy-setting authority to be a directing mind under the common law. In such a circumstance, the criminal trial would succeed even though the civil trial would be unsuccessful. In other words, the government would receive a fine from the criminal defendant, but the civil plaintiff would go without recompense for the same actions that were used to justify the criminal conviction. There are many reasons why this would seem strange. This hypothetical result would seem most incongruous given the higher burden of proof on the prosecution in a criminal trial as compared to its civil counterpart.

If the questions are the same, however, it may be that the first trial could answer all the relevant questions to a standard higher than that of the second trial. For example, if (1) the same questions were asked; (2) the criminal trial were to occur before the civil trial; and (3) the result in the criminal trial were to hold the corporation liable, then the result in the civil trial would generally follow from those findings. Similarly, assume that the civil trial is held prior to the criminal proceeding. In such a case, if the civil trial establishes that the person who committed the relevant act is not a senior officer of the corporation, then at the very least, this should give criminal prosecutors pause to assess whether they can in fact establish the contrary beyond a reasonable doubt. In other words, by re-establishing parity between the civil and criminal uses of the doctrine, there will be an opportunity for economy of

[2004] I S.C.R. 436. However, there are cases where courts have alluded to the fact that direct liability (that is, using the identification doctrine) may be available even though vicarious liability, is or may not be, available: see Neliz v. Dyck (2001), 52 O.R. (3d) 458 at para. 33 (C.A.) [Nelizz]. Here, the Court of Appeal held that consent was made out on the facts, and that therefore, battery was not committed by anyone. Nonetheless, the Court held that it was possible (though not on these facts) for a corporation to be directly liable for the intentional tort of battery. See also J. Anthony VanDuzer, The Lonv of Parmerships and Corporations, 2d ed. Essentials of Canadian Law (Toronto: Irwin Law, 2003) at 176. where VanDuzer establishes that the principles for direct corporate liability for torts is the same as it is for criminal liability. In other words. direct corporate liability is based on the identification doctrine. In any event, the case's referred to in this article establish two principles. First, there are circumstances in which vicarious liabitity principles do not apply to torts (intentional or otherwise). On this point, sec Lennard's Carrying and Rhone, supra note 9, and Nelitz. Second, the application of the identification doctrine in civil law when used as a defence to a lawsuit by the corporation is very well entrenched in Canadian law. Therefore, it is an open question as to how exactly the relationship between the principles of vicarious liability and those at issue in the application of the identification doctrine will play out over time. 
judicial resources. This opportunity is lost if the civil and criminal sides of the identification doctrine are not harmonized.

The third rationale lies in the similarity of purpose between the two uses of the doctrine. The fact is that, whatever the circumstances of its application, the identification doctrine is designed to answer one question: when should an individual's mental state be considered to be that of the corporation? Given that the question to be answered is the same in both contexts - civil and criminal - should the methodology for answering that not also begin at the same point? A corporation is a legal person. ${ }^{130} \mathrm{We}$ are in the process of assessing whether this legal person has a given mental state. At least at the level of theory, it would seem logical that the same test be applied to answer that one question.

\section{Common Law vs. Statute - Which Should Prevall?}

These three rationales make a case for harmonization of the two civil and criminal standards when invoking the identification doctrine. Assuming that the case made above is a convincing one, an additional question arises for brief discussion: if we are to harmonize the tests in the civil and criminal uses of the identification doctrine, should we adopt the criminal version into the civil context? Or would the reverse be the better course? There are two ways to answer this debate. At one level, this question is relatively simple to resolve. The criminal side of the equation is statutory; the civil side is a product of the common law. Parliamentary supremacy holds that the common law cannot overrule a statute. That, in and of itself, is sufficient to resolve this issue.

This analysis is no doubt correct. But even so, there are still compelling substantive reasons why the statutory language is better than its common law counterpart. Although there are several possible improvements to discuss in this section, ${ }^{131}$ it is only necessary to focus on two of them. The first of these is the change from a directing mind to a senior officer. The second change of interest is the ability to hold the corporation liable for a crime even if the senior officer is not liable at all. Both of these changes have been explained above. ${ }^{132}$

The first change means that a policy-setter need not be involved in the wrongdoing; a manager who puts into operation the policy set by others is sufficient. In my view, the change is a positive one. After all, policy would not matter much when the managers charged with turning broad, abstract statements of policy into actions by individual employees ignore that policy with impunity. In other words, if managers ignore the policy created by those above them in the corporate hierarchy, then the policy is merely words and is nothing more than an aspirational statement honoured more in its breach, as opposed to a true representation of corporate action. Words are cheap. Actions should, and do, speak far louder than words. The statute recognizes this fundamental truth, and in essence, changes the law to conform to what

See Salomon and $C B C A$, supra note 10 and accompanying lext.

For a more detailed analysis of the following argument, see Macl'herson, "Lxitending Corporate Criminal Liability?," supra note 106, and Darey L. MacPherson, "Relorming the doetrine of attribution: a Canadian solution to British concerns?" in Stephen Tully, ed., Research Handbook on Corporate Legal Responsibility (London: Edward Elgar, 2005) 194 [MacPherson, "Reforming the Doctrine of Attribution"].

See Part V.A, above. 
one might expect. One might try thinking of it this way: imagine that an individual committed a crime and then said to the police, "But I have a policy against doing that. Sure, I broke that policy and I feel badly about it." In such a case, would the liability of the accused be any different than a person without a policy against the committing the crime? Of course society would not accept such a defence: ${ }^{133}$ why should it be different for corporate persons? While the analogy to human beings is not perfect in that human beings are generally responsible only for their own acts, and corporate persons can be saddled with responsibility for the actions of others over whom the corporation may or may not have meaningful supervision (because, of course, in reality, corporations cannot commit acts of their own), the analogy is sufficiently accurate in that it raises legitimate questions about the common law's previous preference for policy-setters as the only conduit for holding the corporation liable for actions requiring proof of mental fault. ${ }^{34}$

The second change to be examined is the ability to hold the corporation liable for a crime requiring proof of mental fault even if the senior officer is not liable for the offence. Section 22.2(c) provides as follows:

In respect of an offence that requires the prosecution to prove fault - other than negligence - an organization is a pany to the offence if, with the intent at least in part to benefit the organization, one of its senior officers

(c) knowing that a representative of the orgunization is or is about to be a parly to the oflenec, does not take all reasonable measures to stop them from being a party to the offence. ${ }^{135}$

If a senior officer becomes aware of the criminal wrongdoing of another person (in this case, a corporate representative), and does nothing to either encourage or assist it, then the senior officer is not, as an individual, criminally responsible for the wrongdoing of the representative. ${ }^{136}$ However, the statutory language makes the corporation liable in these circumstances.

This leaves aside issues of sentencing. Expressions of remorse are relevant at the sentencing stage of the proceedings: sec Allan Manson, The Law of Sentencing. Essentials of Canadian Law (Toronto: Irwin Law, 2001) at 133; Clayton C. Ruby el al., Senrencing, 6th ed. (Markham, Ont.: LexisNexis Canada, 2004) at para. 5.102.

It is important to point out that the Act fo Amend the Criminal Code does change the level of authority necessarily to invoke the identification theory (from policy-setters, such as the board of directors, to midlevel managers with operational authority). Nevertheless, it does not adopt the vicarious-liability approach of the U.S. courts. Not just any act of any employee will make the corporation liuble lor the crime at issue. The knowledge or involvement of a "senior officer" is necessary in Canada. Therefore. the identification theory is not being blurred with vicarious liability principles. Interestingly, in the 1940s, there was a brief period where the courts of the United Kingdom flirted with the idea of vicarious liability for corporations in criminal prosecutions. For a fuller discussion of this point, see Mucl'herson, "Reforming the Doctrine of Attribution," supra note 131 at 191. This was before Tesco, supra note 79. firmly entrenched the identification doctrine in U.K. jurisprudence. 
This is an improvement over the common law in that the statute now demands communication between the members of corporate management with respect to what each knows about the corporation's misbehaviour that could potentially carry the corporation into the criminal sphere. When a person manages a portion, but not all, of the corporation's activities, this can only be done meaningfully and effectively if one has at least a basic understanding of the overall plan for the corporation. For example, the vice-president of marketing cannot effectively plan the marketing strategy if he or she does not understand the overall financial plan for the corporation, as well as understanding the production timetable for new products. Therefore, the idea of splendid isolation of each member of management does not ordinarily work in the world of business. Yet, the common law identification doctrine functioned on the basis of considering each member of management separately from any other manager because the common law required that, generally, the directing mind be liable for the offence in order for the corporation to be convicted. By removing this splendid isolation for directing minds, the statute more accurately reflects modern corporate reality. ${ }^{137}$

\section{What if the. Criminal. Attribution RULe. is INAPPropriate in Given CirCumstances?}

An argument has been made above that the common law identification doctrine, when applied in civil cases, should be harmonized with the statutory language now applicable in the criminal sphere. One question remains to be considered: what if there is a fundamental difference between the criminal law and the civil context such that the statutory rule, as currently formulated, would not work in the civil context? It could be argued that in particular cases, the application of the criminal test may be inappropriate for some types of civil cases. Such a concern is rightfully acknowledged and acceded to. However, there are at least two ways to deal with this legitimate concern.

First, any problems in terms of application to a given fact scenario should not have any impact at the level of theory. Interestingly, the difference between the level of theory and the level of application of the theoretical test has already been acknowledged in this context. In Canadian Dredge itself, Estey J., writing for the Court, accepted as a matter of theory the general statement of the test for the identification doctrine propounded by the members of the House of Lords in Tesco. ${ }^{138}$ Notwithstanding the acceptance of the test from "across the pond" however, Estey J. had the following to say concerning its application to a given set of facts:

In St. Lawrence, supra, und other authorities, a corporation may, by this means, have more than one directing mind. This must be particularly so in a country such as Canada where corporate operations are frequently

This is not to say that the Act 10 Amend the Criminal Code does not have flaws. For example, the common law formulation of the potential defenees to the application of the identification doctrine is actually superior to that offered hy the statute: see MacPherson, "Extending Corporate Criminal Liability," supra note 106 at 267-71: MacPherson, "Reforming the Doctrine of Attribution," supra note 131 at 207. However, on the whole, the statutory reform is a positive development when compared to its common law cousin. Therefore, if the choice is between the common law and the statute, the latter must prevail, notwithstanding its acknowledged flaws. Put another way, the statute is on balance better than its common law predecessor. 
geographically widespread. The transponation companies, for example, must of necessity operate by the delegation and subdelegation of authority from the corporate centre; by the division and subdivision of the corporate brain; and by decentralizing by delegation the guiding forces in the corporate undertaking. The application of the identification mle in Tesco, supra, may not accord with the realities of life in our country, however appropriate we may find to be the enunciation of the abstract principles of law there made. ${ }^{139}$

Thus, it is clear that while the test is fairly simple to state, it is also sufficiently elastic to respond to the variety of circumstances in which it is applied. So, if there are circumstances which may make the application of the established test inappropriate, the courts have sufficient flexibility to adjust it accordingly. Put another way, the test is designed to achieve policy ends. If the application of the test in a given set of circumstances does not serve policy ends, then a different rule can and should be formulated which achieves those same policy goals.

The second answer to this concern is related to the first. A policy-oriented approach works not only to separate theory from its application, but it may also assist in justifying alteration of the test to better fit a given set of circumstances. This has alseady been done when it comes to the use of the identification doctrine in other jurisdictions. In Meridian Global Funds Management Asia Lid. v. Securities Commission, ${ }^{140}$ the Judicial Committee of the Privy Council (JCPC) was confronted with a situation where one corporation was required to report the acquisition of the shares of another, as soon as the shareholder became aware of the acquisition. Two investment managers of Meridian were aware of the acquisition. Meridian alleged that the application of the identification doctrine would mean that Meridian was not caught by the section since the investment managers were not sufficiently high up in the corporate hierarchy to be directing minds of Meridian. Rather than dealing directly with this argument, the JCPC formulated a special rule of attribution to cover the situation before it. Lord Hoffman, for their Lordships, wrote:

\footnotetext{
The policy of [the notice section] is to compel, in fast-moving markets, the immediate diselosure of the identity of persons who become substantial security holders in public issuers. Notice must be given as soon as that person knows that he has become a substantial security holder. In the case of a corporate security holder, what rule should be implied as to the person whose knowledge for this purpose is to count as the knowledge of the company? Suruly [it is] the person who, with the authority of the company, acquired the relevant interest. Otherwise the policy of the Act would be deleated. Companies would be able to allow employees to acquire interests on their behalf which made them substantial security holders but would not have to report them until the board or someone else in senior management got to know about it. This would put a premium on the board paying as little attention as possible to what its investment managers were doing. ${ }^{1+1}$
}

The Meridian decision was written by an English judge, although the JCPC was technically sitting as the final court of appeal for New Zealand. However, at least one subsequent case has indicated that the Meridian gloss is only a limited change to the 
identification doctrine. ${ }^{142}$ By the very terms of the decision, the gloss will apply only when the policy that the legislation was designed to serve would be negated by the unamended application of the identification doctrine simpliciter.

At least one other case has explicitly recognized the distinction between the policy issues at stake in the use of the identification doctrine as a sword on the one hand, and those which are of concern when it is being used as a shield on the other. In $R . v$. Rozeik, ${ }^{143}$ the identification doctrine was invoked in a novel way. The individual defendant was charged with obtaining property by deception under the Theft Act $1968 . .^{144}$ The prosecution claimed that the accused had defrauded two finance companies, leading to 12 indictments. ${ }^{145}$ The defence responded by alleging that there was no offence because there was no deception on the facts as in each case, there was an employee of the alleged victim who was aware of the true state of affairs. ${ }^{1+6}$ Although this is a criminal, as opposed to a civil, context, it is clear that the identification doctrine is being used here against the corporation, by someone who is alleged to have defrauded it, to deny responsibility for the consequences that would otherwise attach to those actions. With respect to the different considerations that apply when the identification doctrine is used as a shield, as opposed to cases in which it is used as a sword, Legatt L.J. held that:

In cases in which the company is the victim, the person or persons who stand for its state of mind may differ from those who do so in cases in which a company is charged with the commission of a criminal offence. The latter are more likely to represent what Viscount Haldane LC called the directing mind and will of the company' (see Lennard's Carnying Co Lud v Asialic Petroleum Co Lud [1915] AC 705 at 713, [1914-15] All ER Rep 280 at 283). In DPP v Ray [1973] 3 All ER 131. [1974] AC 370 the defendant was charged with dishonestly obtuining by deception a pecuniary advantage in the form of a meal for which he evaded payment. It was the waiter who was held to have been deceived, and the position would have been no different had the deception been perpetrated in a restaurant run by a company rather than a local Chinest restaurant which may not have been. ${ }^{147}$

Ultimately, the conviction originally entered in the case was quashed based on errors in the trial judge's charge to the jury. ${ }^{148}$ Therefore, it was not necessary for the Court to finally resolve how the cases in which the identification doctrine is used as a shield differ from the cases where it is utilized as a sword. Nonetheless, Meridian and Rozeik establish that the doctrine is sufficiently flexible to adapt to unusual circumstances should the need arise. In other words, the courts should not feel bound into a straitjacket by the doctrine; the doctrine exists to serve specific policy ends. If and when the application of the doctrine in given circumstance fails to serve those ends or, even worse, would run counter to them, then an alternative that is capable of accomplishing the same goals should be considered.

142 See Aftomey-General's Reference, supra note 116 at 796.

143 [1996] 3 All E.R. $2 \% 1$ (C.A.) [Rozeik].

the (U.K.), 1968. c. 60. s. 15.

its Rozeik, supra note 143 at $282-83$.

146 loid. at 283.

147 Jbid. at 287.

148 lbid. at 288. 
As in Rozeik, it is unnecessary, and perhaps even impossible, to list in advance all the potential circumstances that might make the application of the new statutory language inappropriate to a civil case. Nonetheless, one example has already been provided: where the application of the doctrine would result in a logical inconsistency, this could provide a policy-based justification for refusing to apply the identification doctrine. By making explicit the underlying policy of the attribution rule, those policy rationales may be challenged by the corporate persons to whom they are to be applied and, if necessary, justified by the other party (such as an insurance company), before the court in the civil action. Either party could then choose to present evidence as to why the identification doctrine is inappropriate, similar to the holding in Meridian.

\section{Conclusion}

The identification doctrine is the means by which the law attributes mental states to corporations. The common law version of the doctrine requires a person with policy-setting authority to have his or her mental state attributed to the corporation, subject to certain defences. Historically, the same criteria for the identification doctrine were applied regardless of whether the criminal or the civil context was at issue in a given case. The cases considering the application of the identification doctrine to a civil case - both in the law of insurance specifically, as well as more generally - have been marked by inconsistency and confusing judicial analysis.

Parliament, through an amendment to the Criminal Code, has altered the identification doctrine as it applies to the criminal sphere. Amongst other changes, the new legislation lowers the level of responsibility that the individual involved in the offence must have within the corporation for there to be attribution of the individual's mental state to the corporation. The level of responsibility is lowered from those with policy-setting authority to those responsible for the management of putting into operation the policy set by others. In many ways, the majority of the statutory changes make it easier for the Crown to prosecute corporations for crimes requiring proof of mental fault. However, at least one of these changes will, to a certain extent, make it more difficult to hold a corporation criminally liable.

The common law is not automatically required to adopt the statutory change because the statutory change is limited to the criminal sphere. Thus, the question arises as to whether the common law identification doctrine that still applies in the areas of torts and insurance should be harmonized with its criminal counterpart. The answer is in the affirmative, for three reasons. The first is historical in that the identification doctrine was originally adopted to resolve a civil case and was only later adopted for the purposes of the criminal law. The civil and criminal applications of the identification doctrine share a common jurisprudential history. Second, if the two contexts, criminal and civil, apply the same test in this regard, this will serve the policy goal of judicial economy, as questions asked in both the civil and criminal trials will be the same, and their resolution in the first trial, be it civil or criminal, may avoid the need for duplication in the later trial. Finally, regardless of the context, the identification doctrine, whether the common-law version or its statutory counterpart, exists to resolve a single legal issuc: when should an individual's mental state be considered to be 
that of the corporation? Thus, the common-law identification doctrine should be harmonized with its statutory counterpart.

Accordingly, the common law should be changed to mirror the statute. Two further points support this conclusion. First, harmonization is a good idea, and the common law cannot force the statute to bend. Therefore, the common law must adjust to reflect the statutory changes. Second, the statute on the whole is substantively closer to current corporate reality than is the common law position. The statute recognizes that policy-setting is meaningful only if the managers charged with the implementation of that policy ensure that the concrete actions taken reflect the policy as set out. If managers ignore the policy with impunity, the policy is useless. Also, the statute requires communication among members of the management team. Both of these changes offer substantive advantages over the previous position under the common law.

Finally, if it is shown that, in a given set of circumstances, the statutory formulation would be inappropriate to the civil context, the suggestions made here are not an analytical straitjacket from which judges cannot escape when necessary. At least two methods of providing elasticity to the judicial task present themselves. First, just because the test is the same at the level of theory does not mean that it is necessarily identical in all circumstances in terms of application. Second, jurisprudence from other countries suggests that the courts are not necessarily obliged to always apply the same test if the use of the test would not promote the policy ends meant to be served by its application.

In this article, a difficult area of law has been reviewed, that being the application of the identification doctrine in the civil law in light of recent statutory changes in a related area. Suggestions have been made about how the law might harmonize these two areas while maintaining flexibility to ensure that the doctrine does not overshoot its policy goals. However, the ideas presented here are not meant to be the end of the story. With any luck, when judges and others confront issues of attribution of mental states to corporations, they will explicitly discuss the policy goals they believe are meant to be achieved by the application of the doctrine. It is hoped that this article will be a catalyst for the necessary debate with respect to these issues. 